\title{
Characterization and genomic analysis of chromate resistant and reducing Bacillus cereus strain SJ1
}

\author{
Minyan $\mathrm{He}^{1,2}$, Xiangyang $\mathrm{Li}^{1}$, Liang Guo ${ }^{1}$, Susan J Miller ${ }^{3}$, Christopher Rensing ${ }^{2 *}$, Gejiao Wang ${ }^{1 *}$
}

\begin{abstract}
Background: Chromium is a toxic heavy metal, which primarily exists in two inorganic forms, $\operatorname{Cr}(\mathrm{VI})$ and $\operatorname{Cr}(\mathrm{III)}$. Chromate $[\mathrm{Cr}(\mathrm{VI})]$ is carcinogenic, mutational, and teratogenic due to its strong oxidizing nature. Biotransformation of $\mathrm{Cr}(\mathrm{VI})$ to less-toxic $\mathrm{Cr}(\mathrm{III})$ by chromate-resistant and reducing bacteria has offered an ecological and economical option for chromate detoxification and bioremediation. However, knowledge of the genetic determinants for chromate resistance and reduction has been limited so far. Our main aim was to investigate chromate resistance and reduction by Bacillus cereus SJ1, and to further study the underlying mechanisms at the molecular level using the obtained genome sequence.

Results: Bacillus cereus SJ1 isolated from chromium-contaminated wastewater of a metal electroplating factory displayed high $\mathrm{Cr}(\mathrm{VI})$ resistance with a minimal inhibitory concentration (MIC) of $30 \mathrm{mM}$ when induced with $\mathrm{Cr}(\mathrm{VI})$. A complete bacterial reduction of $1 \mathrm{mM} \mathrm{Cr}(\mathrm{VI})$ was achieved within $57 \mathrm{~h}$. By genome sequence analysis, a putative chromate transport operon, $c h r l A 1$, and two additional $c h r A$ genes encoding putative chromate transporters that likely confer chromate resistance were identified. Furthermore, we also found an azoreductase gene azo $R$ and four nitroreductase genes nitR possibly involved in chromate reduction. Using reverse transcription PCR (RT-PCR) technology, it was shown that expression of adjacent genes chrA1 and chrl was induced in response to $\mathrm{Cr}(\mathrm{VI})$ but expression of the other two chromate transporter genes chrA2 and chrA3 was constitutive. In contrast, chromate reduction was constitutive in both phenotypic and gene expression analyses. The presence of a resolvase gene upstream of chrlA1, an arsenic resistance operon and a gene encoding Tn7-like transposition proteins ABBCCCD downstream of chrlA1 in B. cereus SJ1 implied the possibility of recent horizontal gene transfer.

Conclusion: Our results indicate that expression of the chromate transporter gene chrA1 was inducible by $\mathrm{Cr}(\mathrm{VI})$ and most likely regulated by the putative transcriptional regulator Chrl. The bacterial $\mathrm{Cr}(\mathrm{VI})$-resistant level was also inducible. The presence of an adjacent arsenic resistance gene cluster nearby the chrlA1 suggested that strong selective pressure by chromium and arsenic could cause bacterial horizontal gene transfer. Such events may favor the survival and increase the resistance level of $B$. cereus SJ1.
\end{abstract}

\section{Background}

The wide use of chromium $(\mathrm{Cr})$ in textile, leather tanning and electroplating industries with subsequent sewage disposal causes severe contamination of global soil-water systems [1,2]. Highly soluble, hexavalent

\footnotetext{
*Correspondence: rensingc@ag.arizona.edu; gejiaow@yahoo.com.cn ${ }^{1}$ State Key Laboratory of Agricultural Microbiology, College of Life Science and Technology, Huazhong Agricultural University, Wuhan, 430070, China 2Department of Soil, Water and Environmental Science, The University of Arizona, Tucson, AZ 85721, USA

Full list of author information is available at the end of the article
}

chromium [chromate, $\mathrm{CrO}_{4}{ }^{2-}$ ] is very toxic. As an analogue of sulfate, chromate can enter bacterial and mammalian cells readily via sulfate transport systems [3]. The subsequent reduction of $\mathrm{Cr}(\mathrm{VI})$ by glutathione, thiols and other metabolites, and coproduction of reactive oxygen species (ROS) that damage DNA and other cellular components are the cause of the carcinogenic, mutational, and teratogenic potential of chromate [4-6]. On the other hand, the trivalent chromium [Cr(III)] is less bioavailable, thermodynamically stable and less toxic [7]. Accordingly, the reduction of toxic $\mathrm{Cr}(\mathrm{VI})$ to
C Biomed Central

() 2010 He et al; licensee BioMed Central Ltd. This is an Open Access article distributed under the terms of the Creative Commons Attribution License (http://creativecommons.org/licenses/by/2.0), which permits unrestricted use, distribution, and reproduction in any medium, provided the original work is properly cited. 
stable $\mathrm{Cr}$ (III) is an efficient way to remove chromate from soil and water systems.

Bioremediation of chromate-contaminated sites, especially when stimulating indigenous microbial communities, is getting more and more attention because of its economical and environmental friendly aspects compared to chemical and physical methods [8-10]. An increasing number of $\mathrm{Cr}(\mathrm{VI})$ - reducing bacteria have been detected and studied including a pseudomonad strain CRB5 [4], Brucella sp. [11], Bacillus sp. strain QC1-2 [12], Burkholderia cepacia MCMB-821 [13] and Thermus scotoductus strain SA-01 [14].

Bacteria have developed different strategies of chromate resistance including chromate efflux and chromate reduction. Efflux of chromate, which is mediated by the chromate transporter protein ChrA, has been confirmed in Pseudomonas aeruginosa [15,16], Ochrobactrum tritici 5bvl1 [17] and Shewanella sp. ANA-3 [18]. Prior studies have not identified a chromate-responsive regulatory protein. Most chromate reduction studies have focused on soluble enzymes encoded by genes located on chromosomes [19]. However, very few of the proteins responsible for chromate reduction have been purified and characterized because of technical difficulties. When examining induction of chromate resistance and reduction genes, several strains including Shewanella oneidensis MR-1 [20], Ochrobactrum tritici 5bvl1 [17] and Ralstonia metallidurans strain CH34 [21] have been shown to contain genes induced by chromate.

In this study, a chromate-resistant and reducing strain Bacillus cereus SJ1 was successfully isolated from chromium contaminated wastewater of a metal electroplating factory. Three chromate transporter related genes $\operatorname{ch} r$, a chromate responsive regulator $c h r I$, four nitR genes encoding nitroreductase and one azoreductase gene $a z o R$ possibly involved in chromate reduction were identified by the draft genome sequence. Using RT-PCR technology, we found that all of the five genes encoding putative chromate reductases appeared to be expressed constitutively. In contrast, the gene chrA1 encoding a transporter with high homology to other transporters linked to chromate resistance was up-regulated by the addition of $\mathrm{Cr}(\mathrm{VI})$ together with the adjacent putative transcriptional regulator $c h r I$. Since $\operatorname{ch} r 1$ is probably regulated by $c h r I$, this suggests identification of the first known chromate-responsive regulator.

\section{Results}

Identification of $\mathrm{Cr}(\mathrm{VI})$-reducing $B$. cereus SJ1 that is highly chromate resistant

Strain SJ1 showing both high $\mathrm{Cr}(\mathrm{VI})$ resistance and reduction abilities was isolated from industrial wastewater of a metal plating factory. SJ1 was a Gram positive, rod shaped bacterium. The $16 \mathrm{~S}$ rDNA sequence was used for bacterial identification. SJ1 showed the highest identity (100\%) with B. cereus $03 \mathrm{BB} 102$ [GenBank: CP001407] and was hereafter referred to as B. cereus SJ1.

B. cereus SJ1 showed rapid reduction of $\mathrm{Cr}(\mathrm{VI})$ aerobically. Cell growth and $\mathrm{Cr}(\mathrm{VI})$ reduction by $B$. cereus SJ1 were monitored spectrophotometrically (Figure 1). The growth rate of SJ1 was rapid. It reached log-phase in 4-6 $h$ in LB medium and the growth rate was decreased by addition of $1 \mathrm{mM}$ chromate. In the first $12 \mathrm{~h}$, the chromate reduction rate was shown to be fastest under optimum $\mathrm{pH}(7.0)$ and temperature $\left(37^{\circ} \mathrm{C}\right)$ conditions (data not shown). After $57 \mathrm{~h}$ of incubation, up to $97 \%$ soluble $\mathrm{Cr}(\mathrm{VI})$ was reduced and white precipitate was visible at the bottom of the flasks [22]. Abiotic $\mathrm{Cr}(\mathrm{VI})$ reduction was not observed in cell-free LB medium (Figure 1).

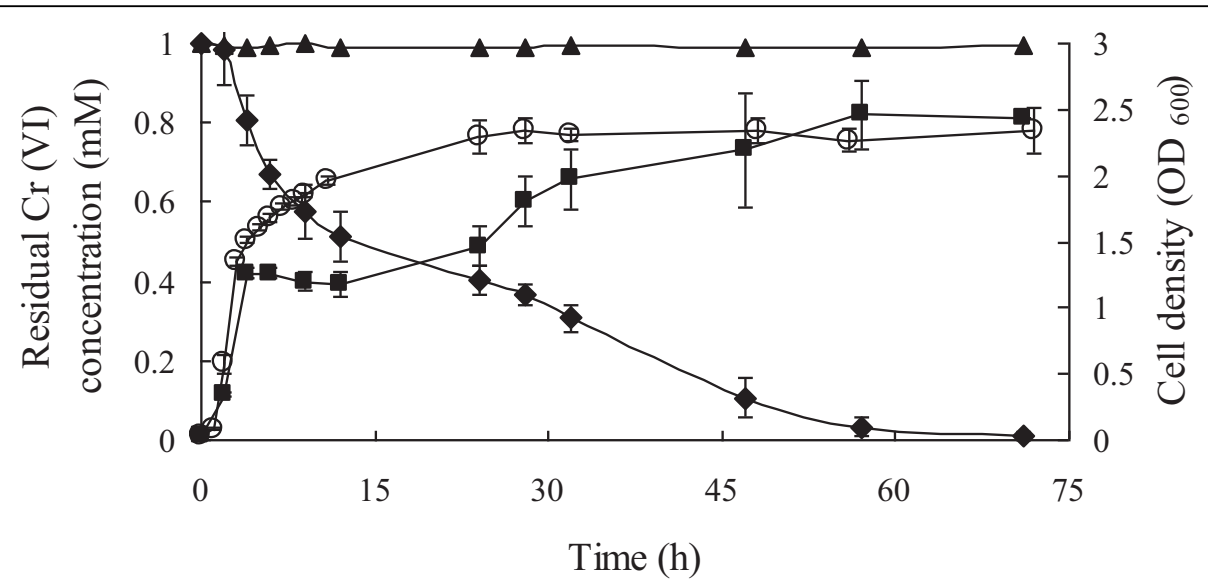

Figure 1 Chromate reduction and growth curves of $B$. cereus SJ1. B. cereus SJ1 growth curves in LB medium with (-) and without (0) 1 mM

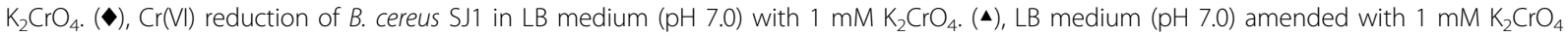
without bacterial inoculation as a control. Error bars represent standard deviation of triplicate samples. 
After cultivation of $B$. cereus SJ1 for 24 h with $1 \mathrm{mM}$ $\mathrm{K}_{2} \mathrm{CrO}_{4}$, the cell became shorter with roughness on the cell surfaces possibable caused by the environmental stress of chromate (Figure 2)

\section{General features of $B$. cereus SJ1 draft genome and genes} involved in chromate metabolism

Draft genome sequence analysis of $B$. cereus SJ1 showed a genome size of about $5.2 \mathrm{Mb}$ distributed in 268 contigs with an average GC content of $35.4 \%$, containing 5,708 putative coding sequences (CDSs). There are 100 tRNA genes representing all 20 amino acids and 6 scattered ribosomal RNA genes identified on the draft genome. The likely origin of replication of the chromosome of $B$. cereus $\mathrm{SJ} 1$ was located in a $9.0 \mathrm{~kb}$ region that included co-localization of six genes $(\mathrm{rpmH}, \mathrm{gyr} A, \operatorname{gyrB}$, $r e c F$, dnaN and $d n a A)$. It was localized by comparing its draft genome to complete genomes of several strains of the B. cereus group though MUMmer3.20.

Three putative chromate transporter genes, chr $A 1$, chrA2 and chrA3 were identified in the genome of $B$. cereus SJ1 (Additional file 1). The chrA1 encoding ChrA protein showed the highest amino acid identity (97\%) with a homologous protein annotated as chromate transporter in Bacillus thuringiensis serovar konkukian str. 97-27 [GenBank: YP036530]. Interestingly, chrA1 gene (locus_tag: BCSJ1_04594, 1,194 bp) located downstream of a potential transcriptional regulator gene $\mathrm{chr}$ (locus_tag: BCSJ1_04599, 309 bp). The region of chrA1 and $c h r I$ also contained several CDSs encoding homologs of Tn7-like transposition proteins and a resolvase that could potentially have been involved in horizontal gene transfer events (Figure 3a). This region covered
$26 \mathrm{~kb}$ sequence and showed lower GC content (32.8\%) compared with the average GC content of $B$. cereus SJ1's whole genome (35.4\%). A similar region was also observed in B. thuringiensis serovar konkukian str. 9727 (Figure 3b), but was absent in other B. cereus genomes. Remarkably, differing from $B$. thuringiensis serovar konkukian str. 97-27, this region of B. cereus SJ1 contained several genes related to arsenic resistance including genes encoding an arsenic resistance operon repressor ArsR, arsenic resistance protein ArsB, arsenate reductase ArsC, arsenic chaperon ArsD and arsenic pump ATPase ArsA (Figure 3a). This may indicate a very recent horizontal gene transfer (HGT) event since genes located upstream of chrIA1 and downstream of arsenic resistance genes were resolvase and Tn7-like transposition protein ABBCCCD in both strains. Furthermore, four nitR genes encoding nitroreductases and a gene $a z o R$, encoding an azoreductase that had previously been reported to catalyze chromate reduction $[19,23]$ were found in the draft genome (Additional file 1, 99-100\% amino acid identities).

\section{Heavy metal tolerance of $B$. cereus SJ1 and putative genes responsible for heavy metal resistance}

Since $B$. cereus SJ1 was isolated from industrial wastewater containing various toxic elements in addition to chromium, the MICs of B. cereus SJ1 for these heavy metals were determined. For $B$. cereus SJ1, the highest resistance was found for $\mathrm{As}(\mathrm{V})$, while $\mathrm{Hg}(\mathrm{II})$ was the most toxic compared to the other metal ions. When $B$. cereus SJ1 was incubated with increasing As concentration, no viable cells were recovered at concentrations above $50 \mathrm{mM}$ As(V) and $4 \mathrm{mM}$ As(III). The MICs of
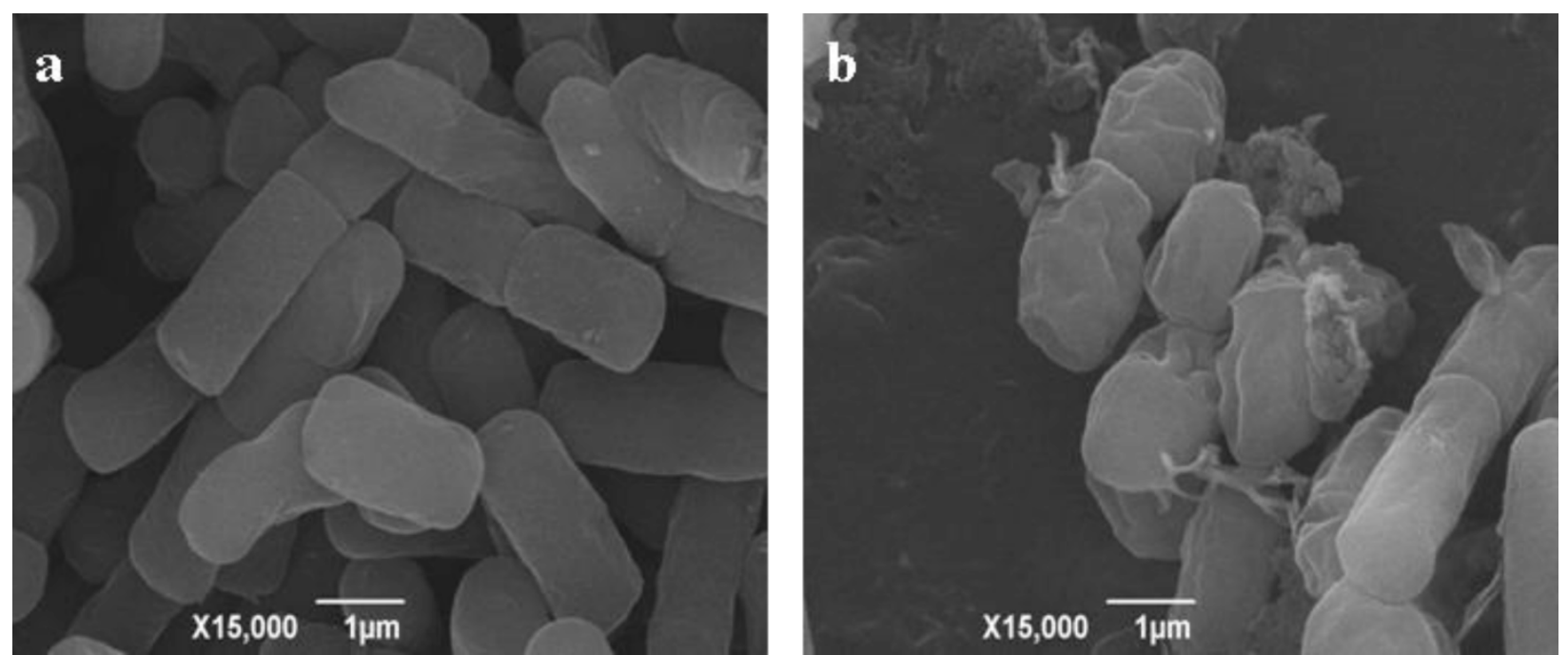

Figure 2 SEM micrographs of $\boldsymbol{B}$. cereus $\mathrm{SJ} 1$ cells. (a), B. cereus $\mathrm{SJ} 1$ cells grown in $\mathrm{LB}$ medium for $24 \mathrm{~h}$ without $\mathrm{K}_{2} \mathrm{CrO}_{4}$; (b), B. cereus SJ1 cells grown in LB medium amended with $1 \mathrm{mM} \mathrm{K}_{2} \mathrm{CrO}_{4}$ for $24 \mathrm{~h}$. Scale bars: $1 \mu \mathrm{m}$. 


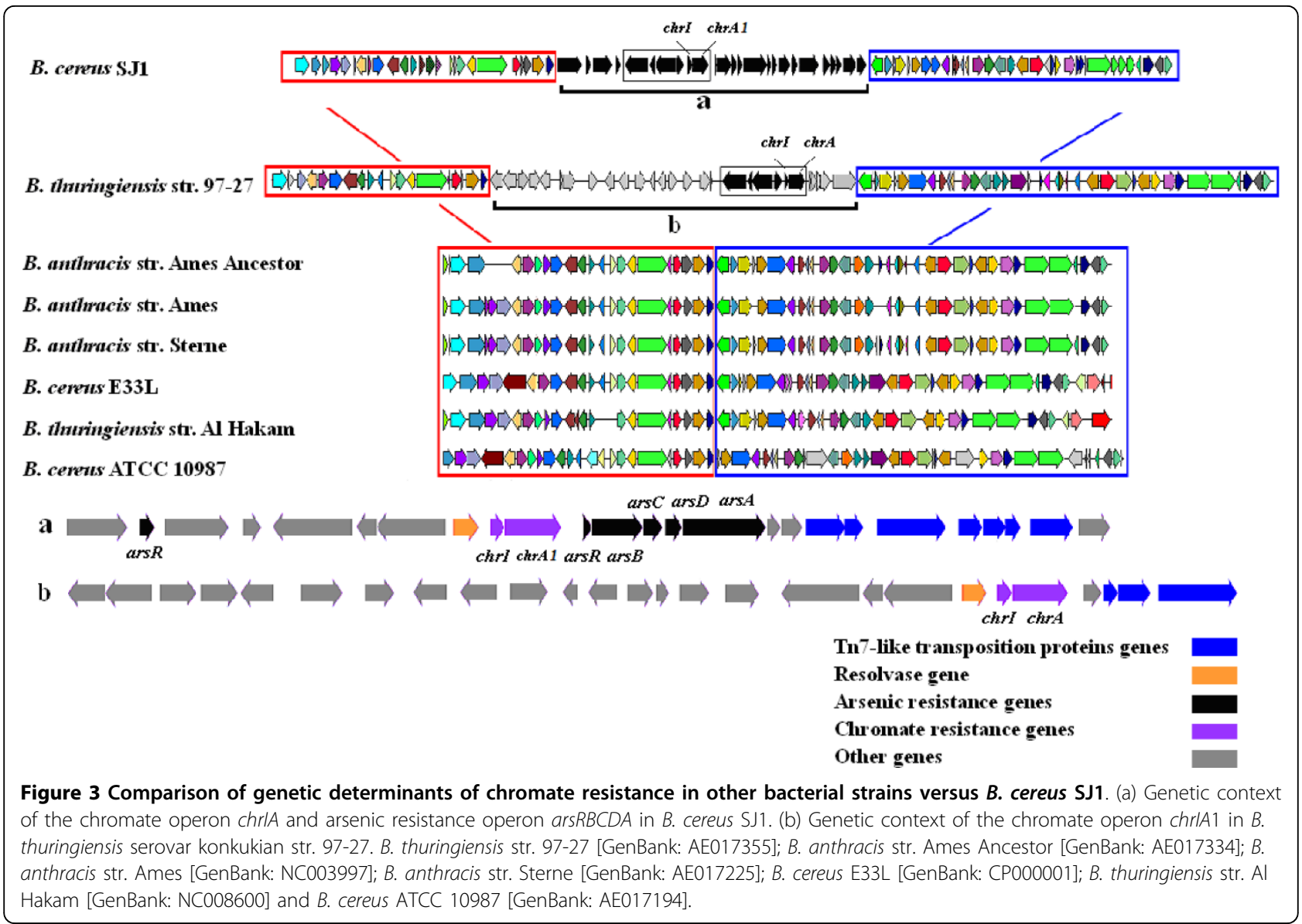

B. cereus $\mathrm{SJ} 1$ for $\mathrm{Cu}(\mathrm{II}), \mathrm{Co}(\mathrm{II}), \mathrm{Ni}(\mathrm{II}), \mathrm{Cd}(\mathrm{II}), \mathrm{Ag}(\mathrm{I})$ and $\mathrm{Hg}$ (II) were $0.9 \mathrm{mM}, 0.8 \mathrm{mM}, 0.7 \mathrm{mM}, 0.2 \mathrm{mM}, 0.02$ $\mathrm{mM}$ and $0.007 \mathrm{mM}$, respectively. In order to survive in such unfavorable habitat, $B$. cereus SJ1 must have various determinants to tolerate such harsh conditions. For example, the copper concentration of the wastewater was as high as $0.65 \mathrm{mM}$ and the MIC of B. cereus SJ1 to copper was $0.9 \mathrm{mM}$ in R2A medium. When we analyzed the genome sequence of $B$. cereus SJ1, several genes related to copper resistance including copper-exporting P-type ATPase CopA, copper export protein CopC, copper resistance protein CopD, copper homeostasis protein CutC and two multicopper oxidases were identified. Furthermore, many other putative heavy metal resistance genes including those for $\mathrm{As}, \mathrm{Zn}, \mathrm{Mn}, \mathrm{Co}, \mathrm{Cd}, \mathrm{Te}$ and $\mathrm{Hg}$ were also identified in the $B$. cereus SJ1 draft genome (Additional file 2).

\section{Chromate reduction is constitutive}

The difference in chromate reducing ability of $B$. cereus SJ1 with and without $\mathrm{Cr}(\mathrm{VI})$ induction was not significant (Figure 4A). Although less rapid chromate reduction was observed in $B$. cereus SJ1 cells induced before inoculation during the first $32 \mathrm{~h}$, both cultures emerged at approximately $85 \%$ chromate reduced within 55 h. No abiotic $\mathrm{Cr}(\mathrm{VI})$ reduction was observed in LB medium without bacterial inoculation. Induction of genes possibly responsible for chromate reduction was also evaluated by RT-PCR. As shown in Figure 5, all the four nitR genes and the $a z o R$ gene were expressed constitutively. The results of RT-PCR were in agreement with the bacterial chromate induction experiment (Figure 4A), strongly indicating no significant regulatory influence of chromate on chromate reduction.

\section{Expression of chrA1 is inducible by chromate}

Using the procedure described in Methods, we found that the uninduced and induced cells grew to similar cell densities in medium containing $5 \mathrm{mM} \mathrm{Cr}(\mathrm{VI})$ as determined spectrophotometrically at $\mathrm{OD}_{600}$. However, the induced cells grew to higher cell densities than the uninduced cells at higher $\mathrm{Cr}(\mathrm{VI})$ concentrations in the growth medium. The MIC of induced B. cereus SJ1 to $\mathrm{K}_{2} \mathrm{CrO}_{4}$ was $30 \mathrm{mM}$ whereas that of the uninduced strain was $20 \mathrm{mM}$ (Figure 4B). 

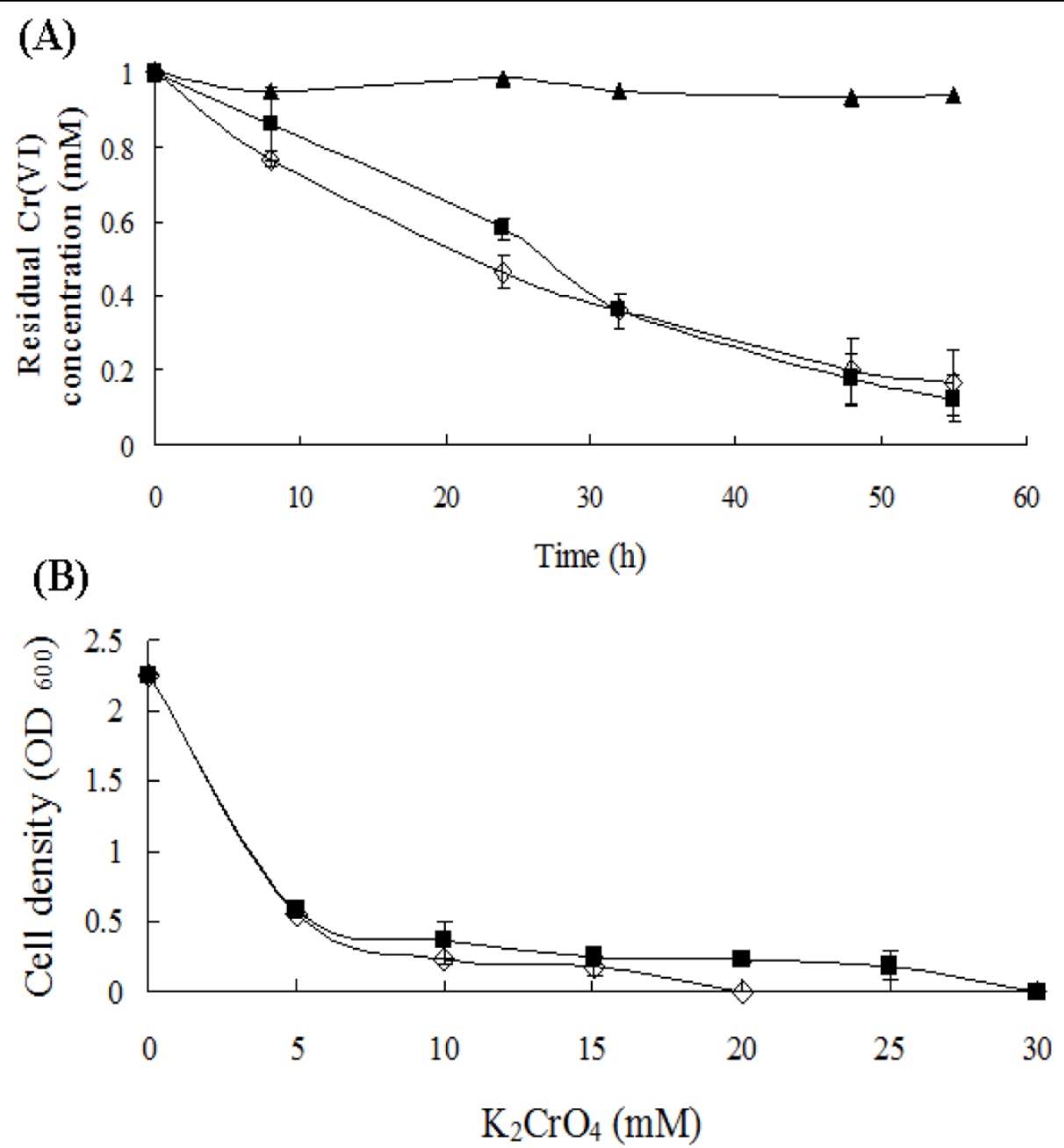

Figure 4 Chromate resistance and reduction of $\mathbf{B}$. cereus SJ1. Chromate reduction (A) and resistance (B) analysis of $B$. cereus $S J 1$ uninduced $(\diamond)$ and induced with $(-) 1 \mathrm{mM} \mathrm{K}_{2} \mathrm{CrO}_{4}$ for $8 \mathrm{~h}$ before bacterial inoculation in $\mathrm{LB}$ medium (pH 7.0). B. cereus SJ1 was incubated for $48 \mathrm{~h}$ before growth was measured for $\mathrm{Cr}$ resistance determination. ( $\mathbf{\Delta})$, amended with $1 \mathrm{mM} \mathrm{K}_{2} \mathrm{CrO}_{4}$ without bacterial inoculation as a control. Error bars represent standard deviation of triplicate samples.

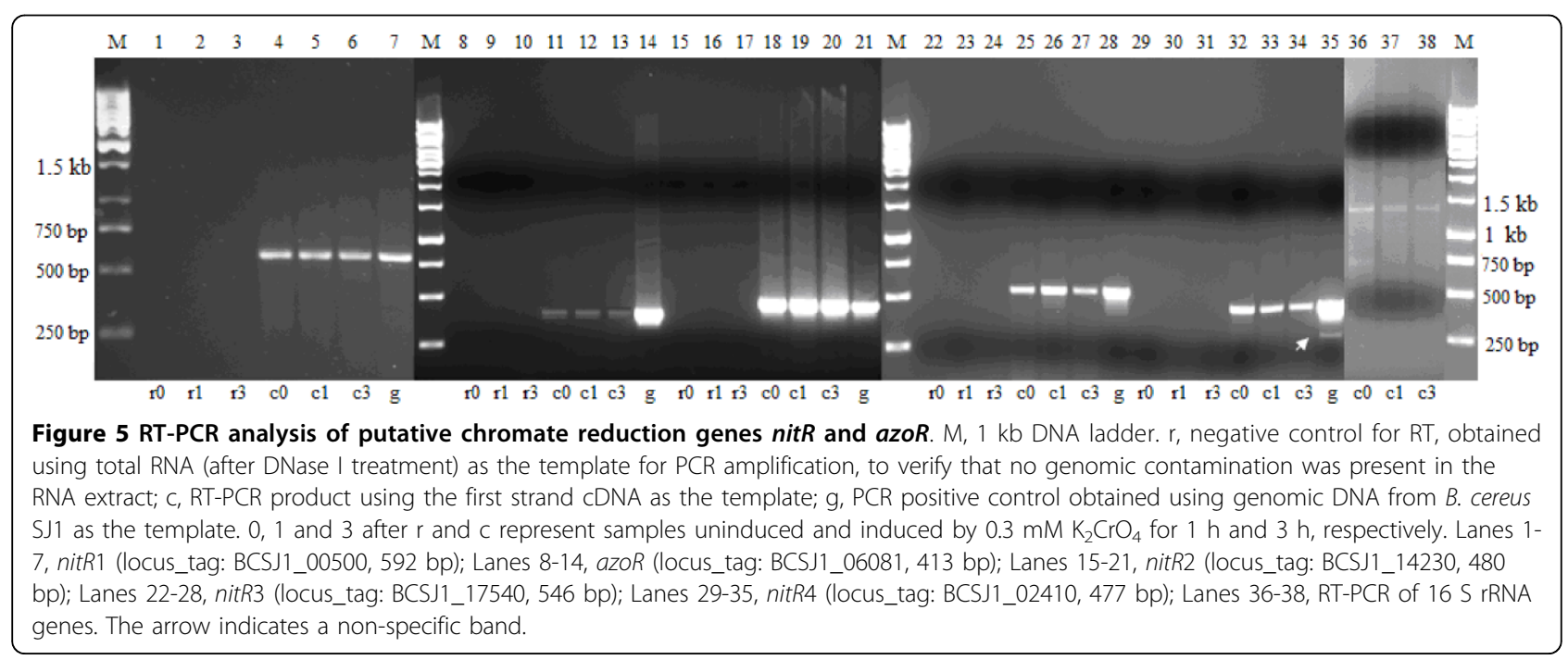




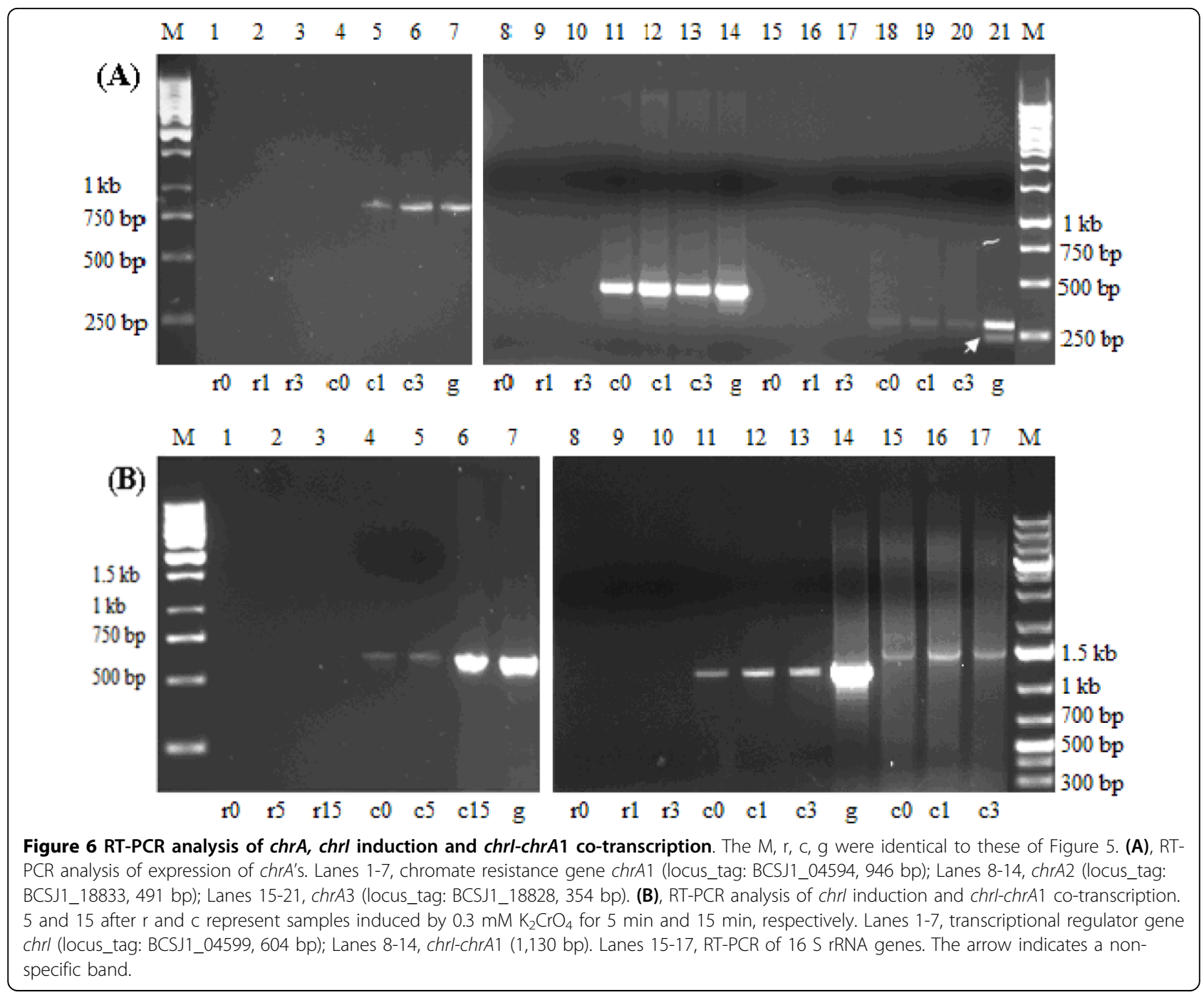

Induction of the different chrA genes was also evaluated by RT-PCR using RNA isolated from cultures grown in the presence and absence of $0.3 \mathrm{mM} \mathrm{Cr}(\mathrm{VI})$ from $0 \mathrm{~h}$ to $3 \mathrm{~h}$ (Figure 6A). A chrA1-specific fragment was clearly visible when $\mathrm{Cr}(\mathrm{VI})$ was added that was absent when no $\mathrm{Cr}(\mathrm{VI})$ was added (Lane 4 vs 5 and 6 ), indicating expression of chrA1 was induced by the addition of $\mathrm{Cr}(\mathrm{VI})$. In contrast, RT-PCR of the other two chrA genes, chrA2 and chrA3, showed that both were expressed constitutively. No products were found using total RNA as the template for PCR amplification, thus indicating the absence of DNA contamination in the total RNA preparations.

\section{chrl, encoding a transcriptional regulator, is regulated by chromate}

The chrI gene located upstream of chrA1 encodes a protein with $98 \%$ amino acid sequence identity to the PadR-family transcriptional regulator from
B. thuringiensis serovar konkukian str. 97-27 [GenBank: YP036529]. As chrI was a potential transcriptional regurator, it should be responsive to the inducer $(\mathrm{Cr})$, so we analyzed the transcription of chrI at 5 and 15 min after addition of $\mathrm{K}_{2} \mathrm{CrO}_{4}$. A very weak PCR product was detected with cDNA from uninduced cells as shown in Figure 6B. The level of the chrI gene transcript was 16-fold higher (analyzed using BandScan 5.0 program) in cells induced for 15 min compared to the uninduced culture (lane 4 vs 6 ), confirming substrate-mediated regulation of chrI. To confirm the hypothesis that chrI-chrA1 was transcribed as a single transcription unit, RT-PCR was carried out with mRNA prepared from B. cereus SJ1 grown with and without $\mathrm{K}_{2} \mathrm{CrO}_{4}(0.3 \mathrm{mM})$ as described above. PCR products of the expected size $(1,130 \mathrm{bp})$ were obtained with cDNA from both induced and uninduced cultures as the templates (Figure 6B), which indicated chrI and chrA1 were arranged as an operon. No PCR products 
were amplified using total RNA as the template that was designed to detect DNA contamination.

The arrangement of chrI genes in an operon together with $\operatorname{chr} A$ encoding a chromate transporter can be detected in both Gram positive and Gram negative bacteria (Additional file 3). An alignment of ChrI homologs was constructed using ChrI of B. cereus SJ1 and other related proteins encoded in operons having a chrI gene adjacent to a chrA gene (Additional file 4). The moreconserved domains were located in the $\mathrm{N}$ - and $\mathrm{C}$-terminal regions. Within the conserved domains, two amino acids, lysine and arginine, were identified that might be involved in chromate binding and recognition.

\section{Discussion}

Chromate-reducing bacteria have been discovered in both contaminated and non-polluted environments $[1,13,24,25]$. In this study, a chromate-resistant strain $B$. cereus SJ1 was isolated from chromium contaminated wastewater of a metal plating factory in China. B. cereus SJ1 showed a rapid growth rate in chromate containing medium and efficient chromate-reducing ability under aerobic conditions. Since the isolation site for $B$. cereus SJ1 was contaminated with as much as $1.89 \mathrm{mg} \mathrm{Cr}$ per liter $(36.28 \mu \mathrm{M})$, we reasoned that genes conferring chromate resistance could be present in this strain. By genome sequencing analysis, we were able to identify a putative chromate transport operon chrIA1 and two additional chrA genes encoding putative chromate transporters that confer chromate resistance. Furthermore, we also found an azoreductase gene azoR and four nit $R$ genes that encode nitroreductases which may catalyze reduction of chromate [19,23].

The membrane transporter protein ChrA has been shown to be responsible for extrusion of chromate ions across the cytoplasmic membrane in $P$. aeruginosa [15,16], Ochrobactrum tritici 5bvl1 [17] and Shewanella sp. ANA3 [18]. It was demonstrated that the chromate transporter ChrA functions as a chemiosmotic pump that extrudes chromate using proton-motive force [15]. ChrA protein belongs to the CHR superfamily which includes dozens of putative homologs from all three domains of life [26]. $\mathrm{Cr}(\mathrm{VI})$ induction of B. cereus SJ1 in this study conferred the ability to survive at a higher chromate concentration. Exposure to chromate resulted in the up-regulation of chrA1 and higher chromate resistance. Possibly increased level of ChrA1 is responsible for higher chromate resistance.

The chrI gene product located upstream of $\operatorname{ch} r A 1$ showed a high homology to PadR-family transcriptional regulators. The padA gene encoding phenolic acid decarboxylase, is a member of the PadR family that has been identified as a transcriptional repressor in Pediococcus pentosaceus [27] and Lactobacillus plantarum
[28]. Although genes encoding PadR homologs located either upstream or downstream of putative chromate transporter gene chrA have been identified in many genera, such as $B$. thuringiensis serovar konkukian str. 97-27 [GenBank: YP036529], Oceanobacillus iheyensis HTE831 [GenBank: NP694199], B. licheniformis ATCC 14580 [GenBank: YP093604) and Alkaliphilus oremlandii OhILAs [GenBank: YP001512811], the real function of a PadR homolog associated with chromate resistance has never been reported. In this study, this gene encoding a PadR homolog was renamed as chrI since it was induced by chromate. By an alignment of most PadR-like regulators which form an operon with the chromate transporter gene $\operatorname{ch} r A$, highly conserved basic amino acids (lysine and arginine) were identified in ChrI and the homologs that might be involved in chromate binding and recognition because they would carry a positive charge under physiological conditions. Possibly the negatively charged oxyanion $\mathrm{CrO}_{4}{ }^{2-}$ would preferentially bind the basic, positively charged amino acids conserved in the putative transcriptional regulator ChrI.

A strong selective pressure for transformation of metal- and metalloid-related resistance genes is present in heavy metal contaminated environments $[29,30]$. Horizontal gene transfer (HGT) events driven by mobile genetic elements, such as phages, plasmids, insertion sequences, integrons and transposons, have been shown to provide microbes with a wide variety of adaptive traits for microbial survival under hostile environmental conditions. In this study, B. cereus SJ1 was isolated from wastewater contaminated with multiple heavy metals. The presence of a resolvase gene upstream of chrIA 1 and an arsenic resistance gene cluster, and the Tn7-like transposition proteins $\mathrm{ABBCCCD}$ gene downstream of the arsenic resistance operon in B. cereus SJ1 but absent in other strains of $B$. cereus implied the possibility of a recent HGT event. Interestingly, other strains of B. cereus harbor a gene encoding CHRD-domain-containing protein adjacent to the chrA gene. Whether these proteins have a regulatory role is currently unknown [31]. In addition, ChrA1 from B. cereus SJ1 is only distantly related to ChrA proteins from other strains of $B$. cereus indicating potential horizontal gene transfer from other Gram-positive bacteria as an adaptation to survive in a highly chromate contaminated environment.

Chromate can be reduced nonenzymatically as well as by various bacterial enzymes. Dihydrolipoamide dehydrogenase from Thermus scotoductus SA-01 [32], azoreductase in Shewanella oneidensis [19] and flavoproteins from $P$. putida and E. coli [3] were previously reported to be associated with $\mathrm{Cr}(\mathrm{VI})$ reduction. Compared to the one electron transfer chromate reductase gene $c h r R$ from $P$. putida, yieF from $E$. coli was proposed to be a more appropriate gene for bioremediation applications 
because of the three-electron transfer ability of its gene product and consequently, the generation of fewer reactive oxygen species (ROS) [33]. In our study, one azoreductase gene azoR and four nitR genes encoding nitroreductase obtained from $B$. cereus $S J 1$ showed high identities with other $\mathrm{Cr}(\mathrm{VI})$ reductases and were expressed constitutively. Since $\mathrm{Cr}(\mathrm{VI})$ reduction of strain SJ1 was not inducible by chromate, other potential chromate reductases in B. cereus SJ1 must also be constitutively expressed and the enzyme activity is probably adventitious.

\section{Conclusion}

This study describes insights into the chromate resistance and reduction capabilities of B. cereus SJ1 using both physiological and molecular techniques. The expression of the chromate transporter gene $c h r A 1$ was inducible by $\mathrm{Cr}(\mathrm{VI})$ and most likely regulated by chrI. Even though the physiological function of ChrI has not been verified due to the absence of a genetic system for this Gram positive strain, ChrI is most likely the first identified chromate responsive regulator. In addition, genome analysis identified a number of putative genes encoding gene products with possible functions in chromate resistance and reduction which may be the basis for the observed high chromate resistance and reduction ability of this strain. Furthermore, possible horizontal gene transfer events indicated in this study may have enabled B. cereus SJ1 to survive in metal (loid) contaminated environments.

\section{Methods}

\section{Isolation of $\mathrm{Cr}(\mathrm{VI})$-resistant and reducing bacteria}

Industrial wastewater samples were obtained from a metal electroplating factory in Guangdong, China. The total concentrations of $\mathrm{Cr}, \mathrm{Cu}, \mathrm{Zn}, \mathrm{Mn}, \mathrm{Pb}, \mathrm{Co}$, As and $\mathrm{Cd}$ in this sample determined by atomic absorption spectrometry were $36.28 \mu \mathrm{M}, 0.65 \mathrm{mM}, 24.88 \mu \mathrm{M}, 7.83$ $\mu \mathrm{M}, 0.49 \mu \mathrm{M}, 0.41 \mu \mathrm{M}, 0.32 \mu \mathrm{M}$, and $0.007 \mu \mathrm{M}$, respectively. Isolation of chromate-resistant and reducing bacteria was performed as described [34]. The abilities of the chromate-resistant bacteria to reduce $\mathrm{Cr}(\mathrm{VI})\left(\mathrm{K}_{2} \mathrm{CrO}_{4}\right)$ were determined using a spectrophotometric method using the reagent 1,5-diphenylcarbazide (DPC) [34]. Several chromate-resistant bacteria were isolated and strain SJ1 was chosen for this study. The $16 \mathrm{~S}$ rDNA of strain SJ1 was obtained from the genome sequence (see below) and analyzed by BlastN searching tools http://www.ncbi.nlm.nih.gov/blast. Cell morphologies were examined under a scanning electron microscope (SEM; JSM-6390, JEOL, Japan) with $20,000 \mathrm{~V}$ accelerating voltage and 15,000 times enlargement.
Determination of the minimal inhibitory concentrations (MICs) of heavy and transition metals and metalloids The MIC, defined as the lowest concentration of heavy metals that inhibited growth in R2A broth (Becton Dickinson, MD, USA), was performed with strain SJ1. A $1 \%$ inoculum of an overnight culture was introduced into R2A medium amended with different concentrations of $\mathrm{CuCl}_{2}, \mathrm{NiCl}_{2}, \mathrm{Co}\left(\mathrm{NO}_{3}\right)_{2}, \mathrm{Na}_{2} \mathrm{HAsO}_{4}, \mathrm{NaAsO}_{2}$, $\mathrm{HgCl}_{2}, \mathrm{CdCl}_{2}$ and $\mathrm{AgNO}_{3}$, incubated at $37^{\circ} \mathrm{C}$ on a rotary shaker at $200 \mathrm{rpm}$ for 3 days. MIC values were determined spectrophotometrically at $\mathrm{OD}_{600}$.

\section{Chromate resistance and reduction assays}

The exponential phase cultures of uninduced, and induced with $1 \mathrm{mM} \mathrm{K} \mathrm{Cr}_{2} \mathrm{O}_{6}$ for $8 \mathrm{~h}$, were adjusted to the same $\mathrm{OD}_{600}$. One hundred microliters of each culture was added to $10 \mathrm{ml}$ fresh $\mathrm{LB}$ medium with increasing amounts of $\mathrm{K}_{2} \mathrm{CrO}_{4}$, and incubated at $37^{\circ} \mathrm{C}$ with $200 \mathrm{rpm}$ shaking for 3 days. The $\mathrm{OD}_{600}$ values were then determined spectrophotometrically. For chromate reduction, the uninduced and induced cultures were prepared as above and inoculated into $100 \mathrm{ml} \mathrm{LB}$ medium amended with $1 \mathrm{mM} \mathrm{K}_{2} \mathrm{CrO}_{4}$ and incubated at $37^{\circ} \mathrm{C}$ on a rotary shaker at $200 \mathrm{rpm}$ for about $60 \mathrm{~h}$. The residual $\mathrm{Cr}(\mathrm{VI})$ concentration was monitored as described above. LB medium with $1 \mathrm{mM} \mathrm{K}_{2} \mathrm{CrO}_{4}$ without bacterial cells was incubated as a negative control to monitor abiotic chromate reduction.

\section{Sequencing of the $B$. cereus SJ1 genome}

High-molecular-mass genomic DNA isolated from B. cereus SJ1 using Blood \& Cell Culture DNA Mini Kit (Qiagen, MD, USA) was used to construct a $4 \mathrm{~kb}$ to 40 $\mathrm{kb}$ random genomic library. Whole genome shotgun sequencing was performed by the University of Arizona Genetics Core facility, using a Roche 454 Genome Sequencer FLX instrument. The B. cereus SJ1 DNA sample was loaded onto one region of a standard fourregion plate. A local Linux computing cluster was used for signal processing on the images produced by the FLX instrument. The Roche gsassembler software version 2.0.01 was used for de novo assembly of the 271,408 reads. Using the default assembly parameters, 141 contigs of length greater than 500 bp were built, along with 127 shorter contigs. These 268 contigs were submitted to the RAST annotation server [35] for subsystem classification and functional annotation. Genome comparison was performed through SEED server http:// rast.nmpdr.org/seedviewer.cgi and the subsequent results were modified manually. GC content was analyzed using CLC Main Workbench 5 program http:// www.clcbio.com. The NCBI Prokaryotic Genomes Automatic Annotation Pipeline was used for gene annotation 
in preparation for data submission to GenBank. http:// www.ncbi.nlm.nih.gov/genomes/static/Pipeline.html.

\section{Gene expression and co-transcription analyses}

RT-PCR was used to assess induced expression and cotranscription of the chromate resistance and reduction related genes of strain SJ1. Total RNA was obtained from mid-exponential phase strain SJ1 cells grown from $0 \mathrm{~h} \mathrm{to} 3 \mathrm{~h}$ in the presence or absence of $0.3 \mathrm{mM}$ $\mathrm{K}_{2} \mathrm{CrO}_{4}$ in $\mathrm{LB}$ medium. Total RNA was isolated by the RNeasy Mini Kit (Qiagen) and then digested with DNase I (Fermentas, MD, USA) to remove any DNA. The $\mathrm{OD}_{260}$ values were then determined spectrophotometrically for the total RNA concentration. Equal amounts of total RNA were used to perform cDNA synthesis using iScript ${ }^{\mathrm{tw}}$ Select cDNA Synthesis Kit (Biorad, CA, USA). Standard PCR programs were used to generate amplicons from $3 \mu \mathrm{l}$ of the reverse transcription reaction mixture using the specific primer pairs listed in Additional file 5. PCR amplification using RNA as template was served as the control to investigate the potential presence of DNA contamination. The relative levels of the cDNAs of RT-PCR were determined by densitometric analyses using BandScan 5.0 software (GLyko Inc., Novato, CA, USA) using $16 \mathrm{~S}$ rRNA genes as references.

\section{Deposition of strain and nucleotide sequences}

B. cereus SJ1 was deposited in The Agricultural Research Service Culture Collection, USA (NRRL http:// nrrl.ncaur.usda.gov) under the accession number of NRRL B-59452. The Whole Genome Shotgun project has been deposited at DDBJ/EMBL/GenBank http:// www.ncbi.nlm.nih.gov/sites/genome under the accession number of ADFM00000000. The version described in this paper is the first version, ADFM01000000.

\section{Acknowledgements}

$\mathrm{MH}$ is supported by the exchanging PhD student scholarship of the Ministry of Education, China. This work is funded by the National Natural Science Foundation of China (30970075).

\section{Author details}

'State Key Laboratory of Agricultural Microbiology, College of Life Science and Technology, Huazhong Agricultural University, Wuhan, 430070, China. ${ }^{2}$ Department of Soil, Water and Environmental Science, The University of Arizona, Tucson, AZ 85721, USA. ${ }^{3}$ Biotechnology Computing Facility, Arizona Research Laboratories, The University of Arizona, Tucson, AZ 85721, USA.

\section{Authors' contributions}

All authors participated in the design of the study and data analyses. MH carried out bacterial isolation, resistant and reduction assay, molecular genetic studies and manuscript preparation. XL carried out the genome analysis. SM carried out genomic sequencing and the whole genome shotgun submission. $L G$ performed the electron microscope analysis. CR participated in the design of the experiments and helped to draft the manuscript. GW is the principal investigator of the funded project. She coordinated the study and helped to draft the manuscript. All authors read and approved the final manuscript.

Received: 15 April 2010 Accepted: 19 August 2010

Published: 19 August 2010

\section{References}

1. Pattanapipitpaisal P, Brown NL, Macaskie LE: Chromate reduction and $16 \mathrm{~S}$ rRNA identification of bacteria isolated from a $\mathrm{Cr}$ (VI)-contaminated site. Appl Microbiol Biotechnol 2001, 57:257-261.

2. Morales-Barrera L, Cristiani-Urbina E: Hexavalent chromium removal by a Trichoderma inhamatum fungal strain isolated from tannery effluent. Water Air Soil Pollut 2008, 187:327-336.

3. Ackerley DF, Gonzalez CF, Park CH, Blake R, Keyhan M, Matin A: Chromatereducing properties of soluble flavoproteins from Pseudomonas putida and Escherichia coli. Appl Environ Microbiol 2004, 70:873-882.

4. McLean J, Beveridge TJ: Chromate reduction by a pseudomonad isolated from a site contaminated with chromated copper arsenate. Appl Environ Microbiol 2001, 67:1076-1084.

5. Chardin B, Dolla A, Chaspoul F, Fardeau ML, Gallice P, Bruschi M: Bioremediation of chromate: thermodynamic analysis of effects of $\mathrm{Cr}(\mathrm{VI})$ on sulfate reducing bacteria. Appl Microbiol Biotechnol 2002, 60:352-360.

6. Klonowska A, Clark ME, Thieman SB, Giles BJ, Wall JD, Fields MW: Hexavalent chromium reduction in Desulfovibrio vulgaris Hildenborough causes transitory inhibition of sulfate reduction and cell growth. Appl Microbiol Biotechnol 2008, 78:1007-1016.

7. Thacker U, Parikh R, Shouche Y, Madamwar D: Hexavalent chromium reduction by Providencia sp. Process Biochem 2006, 41:1332-1337.

8. Smith WL, Gadd GM: Reduction and precipitation of chromate by mixed culture sulphate-reducing bacterial biofilms. J of Appl Microbiol 2000, 88:983-991.

9. Viera $\mathrm{M}$, Curutchet $\mathrm{G}$, Donati $\mathrm{E}: \mathrm{A}$ combined bacterial process for the reduction and immobilization of chromium. Int Biodeterior \& Biodegrad 2003, 52:31-34.

10. Poopal AC, Laxman RS: Hexavalent chromate reduction by immobilized Streptomyces griseus. Biotechnol Lett 2008, 30:1005-1010.

11. Thacker U, Parikh R, Shouche Y, Madamwar D: Reduction of chromate by cell-free extract of Brucella sp. isolated from $\mathrm{Cr}(\mathrm{VI})$ contaminated sites. Bioresour Technol 2007, 98:1541-1547.

12. Campos J, Martinez-Pacheco M, Cervantes C: Hexavalent-chromium reduction by a chromate-resistant Bacillus sp. strain. Antonie van Leeuwenhoek 1995, 68:203-208.

13. Wani R, Kodam KM, Gawai KR, Dhakephalkar PK: Chromate reduction by Burkholderia cepacia MCMB-821, isolated from the pristine habitat of alkaline crater lake. Appl Microbiol Biotechnol 2007, 75:627-632.

14. Opperman DJ, Heerden EV: Aerobic $\mathrm{Cr}(\mathrm{VI})$ reduction by Thermus scotoductus strain SA-01. J of Appl Microbiol 2007, 103:1364-5072.

15. Alvarez $A H$, Moreno-sanchez $R$, Cervantes $C$ : Chromate efflux by means of the ChrA chromate resistance protein from Pseudomonas aeruginosa. $J$ Bacteriol 1999, 181:7398-7400.

16. Pimentel BE, Moreno-Sanchez R, Cervantes C: Efflux of chromate by Pseudomonas aeruginosa cells expressing the ChrA protein. FEMS Microbiol Lett 2002, 212:249-254.

17. Branco R, Chung AP, Johnston T, Gurel V, Morais P, Zhitkovich A: The chromate-inducible chrBACF operon from the transposable element TnOtChr confers resistance to chromium(VI) and superoxide. J Bacteriol 2008, 190:6996-7003.

18. Aguilar-Barajas E, Paluscio E, Cervantes C, Rensing C: Expression of chromate resistance genes from Shewanella sp. strain ANA-3 in Escherichia coli. FEMS Microbiol Lett 2008, 285:97-100

19. Mugerfeld I, Law BA, Wickham GS, Thompson DK: A putative azoreductase gene is involved in the Shewanella oneidensis response to heavy metal stress. Appl Microbiol Biotechnol 2009, 82:1131-1141.

20. Thompson MR, VerBerkmoes NC, Chourey K, Shah M, Thompson DK Hettich RL: Dosage-dependent proteome response of Shewanella oneidensis MR-1 to acute chromate challenge. J Proteome Res 2007, 6:1745-1757.

21. Juhnke S, Peitzsch N, Hubener N, GroBe C, Nies DH: New genes involved in chromate resistance in Ralstonia metallidurans strain $\mathrm{CH} 34$. Arch Microbiol 2002, 179:15-25. 
22. Puzon GJ, Roberts AG, Kramer DM, Xun L: Formation of soluble organochromium(III) complexes after chromate reduction in the presence of cellular organics. Environ Sci Technol 2005, 39:2811-2817.

23. Kwak YH, Lee DS, Kim HB: Vibrio harveyi nitroreductase is also a chromate reductase. Appl Environ Microbiol 2003, 69:4390-4395.

24. Pal A, Dutta S, Paul AK: Reduction of Hexavalent Chromium by Cell-Free Extract of Bacillus sphaericus AND 303 Isolated from Serpentine Soil. Curr Microbiol 2005, 51:327-330.

25. Yewalkar SN, Dhumal KN, Sainis JK: Chromium (VI)-reducing Chlorella spp. isolated from disposal sites of paper-pulp and electroplating industry. J Appl Phycol 2007, 19:459-465.

26. Diaz-Perez C, Cervantes C, Campos-Garcia J, Julian-Sanchez A, RiverosRosas $\mathrm{H}$ : Phylogenetic analysis of the chromate ion transporter (CHR) superfamily. FEBS J 2007, 274:6215-6227.

27. Barthelmebs L, Lecomte B, Divies C, Cavin J: Inducible metabolism of phenolic acids in Pediococcus pentosaceus is encoded by an autoregulated operon which involves a new class of negative transcriptional regulator. J Bacterio/ 2000, 182:6724-6731.

28. Gury J, Barthelmebs L, Tran NP, Diviès C, Cavin J: Cloning, deletion, and characterization of PadR, the transcriptional repressor of the phenolic acid decarboxylase-encoding padA gene of Lactobacillus plantarum. Appl Environ Microbiol 2004, 70:2146-2153.

29. Ryan RP, Ryan DJ, Dowling DN: Multiple metal resistant transferable phenotypes in bacteria as indicators of soil contamination with heavy metals. J Soil Sed 2005, 5(2):95-100.

30. Cai L, Liu GH, Rensing C, Wang GJ: Genes involved in arsenic transformation and resistance associated with different levels of arseniccontaminated soils. BMC Microbiol 2009, 9:4.

31. Hyvonen M: CHRD, a novel domain in the BMP inhibitor chordin, is also found in microbial proteins. Trends Biochem Sci 2003, 28:470-473.

32. Opperman DJ, Heerden EV: Amembrane-associated protein with $\mathrm{Cr}(\mathrm{VI})$ reducing activity from Thermus scotoductus SA-01. FEMS Microbiol Lett 2007, 280:210-218

33. Ackerley DF, Gonzalez CF, Keyhan M, Blake R, Matin A: Mechanism of chromate reduction by the Escherichia coli protein, NfsA, and the role of different chromate reductases in minimizing oxidative stress during chromate reduction. Environ Microbiol 2004, 6:851-860

34. Yang J, He M, Wang G: Removal of toxic chromate using free and immobilized $\mathrm{Cr}(\mathrm{VI})$-reducing bacterial cells of Intrasporangium sp. Q5-1. World J Microbiol Biotechnol 2009, 25:1579-1587.

35. Aziz RK, Bartels D, Best AA, DeJongh M, Disz T, Edwards RA, Formsma K, Gerdes S, Glass EM, Kubal M, Meyer F, Olsen GJ, Olson R, Osterman AL, Overbeek RA, McNeil LK, Paarmann D, Paczian T, Parrello B, Pusch GD, Reich C, Stevens R, Vassieva O, Vonstein V, Wilke A, Zagnitko O: The RAST Server: rapid annotations using subsystems technology. BMC Genomics 2008, 9:75.

doi:10.1186/1471-2180-10-221

Cite this article as: He et al:: Characterization and genomic analysis of chromate resistant and reducing Bacillus cereus strain SJ1. BMC

Microbiology 2010 10:221.

\section{Submit your next manuscript to BioMed Central and take full advantage of:}

- Convenient online submission

- Thorough peer review

- No space constraints or color figure charges

- Immediate publication on acceptance

- Inclusion in PubMed, CAS, Scopus and Google Scholar

- Research which is freely available for redistribution

Submit your manuscript at www.biomedcentral.com/submit
Biomed Central 